Article

\title{
Democracy at Stake: Self-Censorship as a Self-Defence Strategy for Journalists
}

\author{
Gerald Walulya * and Goretti L. Nassanga \\ Department of Journalism \& Communication, Makerere University, Kampala, Uganda; E-Mails: werald@gmail.com (G.W.), \\ gnassanga@gmail.com (G.L.N.) \\ * Corresponding author
}

Submitted: 30 September 2019 | Accepted: 30 December 2019 | Published: 25 February 2020

\begin{abstract}
The media play an essential role of informing and mobilising voters as well as facilitating a two-way communication process between citizens and those vying for electoral offices during elections. This allows citizens to get information on various issues from the contenders, which largely informs their electoral decisions. In most less democratic societies however, this media function is increasingly becoming difficult to fulfil due to challenges journalists encounter during electoral processes. Using Uganda's last general elections in 2016 as a case study, this article discusses the safety of journalists during elections basing on findings from a bigger study on the media coverage of the 2016 elections, supplemented by in-depth interviews with 10 journalists who covered the elections. In addition, the analysis makes reference to the 2016 Uganda Press Freedom Index. Findings of this research show that journalists face more safety and security risks during elections particularly perpetuated by state security agencies. Compared to previous elections, the 2016 elections also recorded the highest number of victims who were female journalists. This article highlights key challenges journalists face during elections, which include: state harassment and intimidation, arrest of those considered critical to the state, and denial of access to important information. Due to concerns of their own safety, journalists have responded to the insecure work environment by engaging in self-censorship, thereby giving biased or limited information to the public. The article identifies gaps that media development agencies can help to close if the media are to play their rightful role in a democratic society, especially during the electoral process.
\end{abstract}

\section{Keywords}

democracy; election reporting; journalists; press freedom; safety; self-censorship; violence

\section{Issue}

This article is part of the issue "Rethinking Safety of Journalists" edited by Kristin Skare Orgeret (Oslo Metropolitan University, Norway) and William Tayeebwa (University of Makerere, Uganda).

(C) 2020 by the authors; licensee Cogitatio (Lisbon, Portugal). This article is licensed under a Creative Commons Attribution 4.0 International License (CC BY).

\section{Introduction}

The 'responsibility to protect' and 'the responsibility to report,' profoundly implicate journalists in the practice of their craft and the conduct of civil societies around the world. They should be seen as indivisible, mutually constitutive, and implicate us all in the conduct and safeguarding of journalists. The protection of journalists and their responsibility to report in and from dangerous places, in violent times, cannot there- fore be simply seen as a matter to do with 'journalists' or, even more broadly, as simply being about 'journalism.' Ultimately it is a matter for all of us, as it reaches deep inside the conduct of human affairs in global society. (Cottle, 2017, p. 29)

The above statement gives the context within which this article is premised. The safety of journalists as they carry out their 'responsibility to report' is no longer a concern of individual nation states, but is now a global con- 
cern, whereby the international community is obliged to come to the defence of journalists' safety, thus warranting evoking the global 'responsibility to protect' (R2P) journalists. The commitment of states to free speech and press freedom has been found deficient and the verdict according to Sarikakis (2017) is that "states have failed to provide for the consistent and systematic protective measures for journalists" (p. 119). This failure can partly account for the increase in numbers of journalists killed every year, especially in wars and conflicts (Cottle, 2017; Orgeret, 2016b, 2016c; UNESCO, 2018a). The global trends and endemic conflicts have contributed to positioning journalists at increased risk and in harm's way (Cottle, 2017). Although there are a few safe havens, Sarikakis (2017) observes that even in stable democracies, journalists remain vulnerable and conditions for journalism and free expression can deteriorate surprisingly fast.

The principle of the R2P was originally meant to be protection of citizens against genocide, war crimes, ethnic cleansing, and crimes against humanity, taken as a responsibility of the state, with the international community intervening if the state failed. However, this has expanded to the R2P potential victims to mass atrocities and people suffering from avoidable catastrophe (Bellamy, 2010; Global Centre for the R2P, 2015; International Commission on Intervention and State Sovereignty, 2001). Due to the increasing number of journalists facing security and safety threats, this has warranted evoking the R2P beyond individual states to the international community.

Mirza (2009) rightly points out that although there is little evidence that supports the existence of a global public sphere, there is no question that globalising trends are made possible with the help of media at both the domestic and international level. Thus, it is difficult to de-link R2P journalists as a local state mandate to the responsibility of the international community. Indeed, organizations like UNESCO, Reporters Sans Frontiers, Committee for the Protection of Journalists, International Crisis Group, and others, have been actively engaged in advancing initiatives for the security and protection of journalists globally. The situation is particularly delicate where journalists have to report from conflict or war zones. The fact that journalists are often persecuted, threatened or harmed during conflicts, affects their ability to report freely (Frere, 2011; Orgeret, 2016a). There is a trend of increased use of second-hand information through wire services, which information is sometimes difficult to interpret to be relevant to local audiences (Høiby \& Ottosen, 2016). When considering safety of journalists, the mind often ponders about killings. As Torsner (2017) explains, while the killings of journalists can be described as the most serious manifestation of danger, there exists a whole range of different types of risks that impact the safety of journalists. These risks often relate to the nature of certain forms of journalismsuch as critique of vested interests or views, exposure of corruption, or reporting on conflict that they may become targets of attack.

Emphasising the vital role media play, Ronning (2016) contends that "there is no doubt that the press plays a critical role in all societies, particularly in defending and promoting democracy and citizens' right to be informed and to debate" (p. 44). Apart from media providing information to citizens, another key core societal role is "to discover illegal actions and protect people from corruption through their watchdog function" (Orgeret, 2016a, p. 15). Since we get most of our information and what we know from the media, including social media, the journalists who are largely responsible for the media output, have a key role to play in any society.

The right to access information presupposes that journalists operate in a conducive safe environment, where they can provide citizens with relevant information that enables them to make informed decisions. However, journalists often face challenges and leave out certain information that can pose security and safety threats to them.

Nohrstedt (2016) regrets that the challenges faced by journalists in war and conflict zones are not problematised by mainstream media, so the general public is uninformed about the risks to freedom of information and concludes that "from a democratic point of view, this is a very dangerous situation" (p. 163), or what he terms as a "muted democracy." Echoing the same fears, a UNESCO (2018a) report observes that "imprisonment of journalists for their legitimate work not only fosters a culture of self-censorship but also impinges on the broader rights of society to obtain information" (p. 148). Of particular interest in this article is the period of elections. During this time, the media and journalists are supposed to provide a platform for contenders to reach the electorate. In the same way, through the media, the electorate receive information from contenders, which the voters base on to make their electoral decisions.

The purpose of this article is to examine the safety of journalists in the course of their work in Uganda, giving special focus to the time of elections. During the pre-election campaigns, at election time and immediate post-election period, there is much tension due to contestation of power as stakes are high, with various contenders trying to win elective positions in government. Sparks (2011) views media as valuable assets and argues that winning political power allows a person to influence the stories covered and the way they are covered. He states that this can be exemplified by the high degree of media politicisation in many countries that is a reflection of the belief that control of the media improves chances of holding onto political power, given media's utility especially in competitive struggles, be they economic or political.

For this article, we consider a political struggle with the analysis based on a bigger study on election coverage in East Africa, using the 2016 Uganda elections as a case study. Media being the major channel through 
which people within the country and beyond get to know what is happening during election time, it is important to analyse and document the kind of work environment that journalists operate in, as relates to their safety and security.

To put the analysis into perspective, the article first gives an overview of the broader global picture on the safety of journalists.

\section{Safety and Security of Journalists at the Global Level}

When examining the R2P journalists by the international community, it is important to recognise the changed media landscape and the concepts of both 'interdependence' and 'globalisation,' which have promoted geographical closeness or cultural proximity that has facilitated media to cross borders to create global media systems (Mirza, 2009). This implies that the safety of journalists has to be considered at the local, regional, and the global levels.

Generally, the security and safety threats to journalists have had a negative impact on the way newsrooms operate. In their investigation on security of journalists, Høiby and Ottosen (2016) found that editors were reluctant to send reporters to conflict zones or on "highrisk assignments in regions affected by political tension" (p. 190), and when they did, they kept them out for a short time, meaning there were fewer first hand observations. They argue that this led to degraded quality and quantity of information from wars and conflict areas, which impacted society at the local and international level. Ntulume (2016) echoes similar observations after her analysis of the Ugandan army intervention in the South Sudan conflict, where she finds that most of the news coverage was a reproduction of the leadership standpoint, with few challenging voices explaining that "journalists seemed to tread carefully appearing to prefer to run with information officials provided, than navigate uncertain territory" (p. 58). The same experience is shared by Skjerdal (2013) after his study of journalism practice in Ethiopia, where he found that there was a culture of self-censorship and discourses of fear in the newsrooms with journalists producing and reproducing a subservient reporting style. These observations tally with those of Sparks (2011), who concludes after his study on South African media that media were very far from the ideal of neutral and objective journalism. However, most times these imbalances are brought about by factors beyond the journalists' control, having more to do with the work environment they operate in. In this article, we explore the different threats to journalists' safety in the course of performing their work professionally.

UNESCO is one of the agencies working towards enhancing press freedom and they are regularly engaged in monitoring the media as part of assessing developments in the media industry worldwide. In a recent world report that assessed among others, the physical, psychological, and digital safety of journalists, it was noted that "trends remain extremely alarming" (UNESCO, 2018a, p. 137). The report cites the case of 530 journalists who were killed, with an average of two deaths per week between 2012 and 2016. In addition, the report points out the high levels of impunity for crimes against journalists, with only $10 \%$ of the 930 cases of death of journalists between 2006-2016 being resolved, which means that it was only in these cases where the perpetrators of the crimes were brought to justice by a court of law. Out of 930 cases that were registered, 33\% were ongoing or unresolved. In at least $55 \%$ of the cases, there was no information on judicial follow-up of investigations (UNESCO, 2018a). Comparatively, Western Europe and North America experienced a lesser degree of impunity with $50 \%$ of the cases resolved, Africa had only $13 \%$ of cases resolved, whereas the Arab states had the highest level of impunity with only $2 \%$ of cases resolved. This implies that there are still high levels of impunity of crimes against journalists in most developing countries as most of the cases either remain unresolved/ongoing or there is no information on their judicial process.

\section{Work Environment for Journalists in Uganda}

Article 29 of the Ugandan Constitution generally guarantees the right to freedom of the media and expression. However, several studies show that the work environment for journalists in Uganda is very restrictive, with journalists facing threats of violence, harassment, intimidation, imprisonment, kidnap, and even death (Foundation for Human Right Initiative [FHRI], 2016; Human Rights Watch, 2016; Ssenoga, 2018; UNESCO, $2018 b)$. These various forms of risk to the safety of journalists do not only limit access to information for citizens but it has "a chilling effect on the ability of Ugandans to critique the president and the government's policies or freely debate critical issues, such as governance and corruption" (Human Rights Watch, 2016, p. 42). The violence can be viewed as part of an ongoing and systematic form of censorship designed to stifle freedom of the press in Uganda (Ssenoga, 2018).

From one radio station (Radio Uganda) and one TV station (UTV) in the 1960s, Uganda has 292 licensed radio stations spread country-wide and 33 operational television stations, mainly in the capital Kampala (Uganda Communications Commission, 2018). With this multiplicity of broadcast stations, one can easily miss-construe this as indicative of a flourishing democracy since citizens ideally would have exposure to more media outlets and better information access. However, this is not the case for Uganda, as was noted in a 2016 pre-election report by Human Rights Watch (2016). The report noted that freedom of the press in Uganda was deceptive explaining that while print journalists in the country's capital, Kampala, may enjoy some relative degree of freedom, journalists outside Kampala-particularly radio journalists upcountry broadcasting in local languagesface challenges often in freely reporting on issues seem- 
ingly sensitive to the ruling party. The report further noted that it was common for journalists and station managers to face threats of suspension or dismissal for providing the opposition with a platform, while radio stations faced the threat of closure. Such threats to journalists tend to entrench the culture of self-censorship.

Like the previous regimes, the current government has reacted towards what is deemed as hostile or subversive media coverage the same way as the colonial administration that tolerated no criticisms (Bichachi, 2013). All this done under the pretext of having a "controlled Press as a necessity to preserve national security and unity" (Sekeba, 2016, p. 147). A challenge that journalists face sometimes is the dual loyalty between the professional demands and calls for nationalism or loyalty to the nation. Skjerdal (2013) describes this situation as having competing loyalties, but points out that these are not static but are more often shifting loyalties that involve dilemmas when dealing with issues considered sensitive, leading to self-censorship.

In a survey that among others assessed Ugandan journalists' perception of their work environment, $77 \%$ respondents revealed that they were intensely harassed and $23 \%$ said they were not. The survey also showed that most journalists faced these security risks relating to their work personally as their media houses often don't have policies to address them. For $80 \%$ of the journalists, their media houses had no policies for safety, while only $20 \%$ had some policies (UNESCO, 2018b). Due to fear for their personal safety, journalists have taken on selfcensorship, rather than to risk the wrath of government and security agencies if reporting on issues considered 'sensitive.' As noted by Ssenoga (2018), journalists in Uganda have borne the brunt of censorship for decades.

The harassment and violence are not only experienced by local journalists but also by foreign correspondents. One such incident was when a Reuters photojournalist, James Akena, who was covering demonstrations demanding for the release of Robert Kyagulanyi (also known as Bobi Wine), a member of the Ugandan parliament and a musician, was beaten, and the video of his beating went viral on social media. President Yoweri Museveni, "tried to explain away the attack saying that it was a case of mistaken identity that the journalist had been mistaken for a camera thief" (Ssenoga, 2018).

It has been noted that while journalists operate under threats daily, the fear to express oneself freely is more pertinent during periods of political contestation or controversy, and restrictions and threats are more pronounced during this time (Friedrich-Ebert-Stiftung \& fesmedia Africa, 2016). When considering the safety of journalists, particular focus is made to journalists covering conflicts of various dimensions including wars, armed conflict, situations of political instability, riots, demonstrations, crisis or tension situations, and election periods. This is a genuine concern as Orgeret (2016c) reveals in her study on challenges of war and conflict coverage. She notes that an increasing number of journalists world- wide have encountered violent aggression while covering civil unrest and demonstrations and some have been killed in the process, which has resulted in an increase of coverage gaps and a growing culture of self-censorship within the media and society. Høiby and Ottosen (2016) came up with similar findings in their study, observing that the security situation for reporters in conflict zones had deteriorated greatly. The duo concludes that "it is evident that there is a close link between lack of security and self-censorship" (Høiby \& Ottosen, 2016, p. 183), adding that the increasing problem of impunity has an impact on freedom of expression on a global scale.

Another area of particular concern for the safety of journalists is during investigative reporting. Often times, the people being investigated are influential individuals in government, holding leadership positions in society or with big businesses. These types of people sometimes threaten journalists who try to expose them in the media. Criminal networks are prepared to use extreme violence to contain and control public information and investigations that threaten their interests. Sometimes journalists become targets or indirect victims when seeking to report on such injustices (Cottle, 2017). A case in point is an investigative journalist, Solomon Serwanjja, who was doing an investigative story for NBS Television on big shots selling medical drugs that were supposed to be free to patients in government hospitals. When word leaked about the story, a hunt started for him. After failing to trace his whereabouts, police picked his wife from their home and the journalist had to come out of hiding before his wife could be released (Yiga, 2019). This demonstrates how threats may go beyond the journalists and affect their families too.

Similar to what takes place in other countries where violence is meted out to both male and female journalists, female journalists in Uganda also experience another dimension of this through sexual harassment, which discourages upcoming female journalists. In addition, female journalists are more exposed in conflict settings that are usually dominated by men and this makes them more vulnerable (Orgeret, 2016a). While there are slightly more females than males in the journalism training institutions in Uganda, the newsrooms are male dominated and journalism is still seen as a 'masculine' job. A study by the Uganda Media Women Association that assessed women's participation in the print media found that only an average $20 \%$ women are involved in print media journalism (World Association for Christian Communication, \& Uganda Media Women's Association, 2015).

A challenge to women covering conflict or wars that Orgeret (2016b, 2016c) identified was the need to have an awareness of cultural norms and practices especially when it comes to how to deal with sources in the field, who would perceive the journalist in her professional capacity and as a woman. The female journalists she interviewed said that they had to develop a situational awareness to be able to recognise certain conversations 
deemed inappropriate and sometimes eye contact that could be construed as flirting. These experiences may not apply to the male journalists.

In the next section we present the methodology applied to collect data used in this article followed by the findings of the study.

\section{Methodology}

The analysis in this article is based on findings from a bigger research project that assessed the press coverage of elections in East Africa's one-party dominant states of Uganda and Tanzania. (Walulya, 2018). In addition to the primary data from the field research, the article supplements this with findings from the 2016 Uganda Press Freedom Index produced by the Human Rights Network for Journalists-Uganda (HRNJ-U). Findings from the above two sources were further supplemented by key informant interviews with a purposively selected sample of 10 journalists, who covered the 2016 elections, out of about 60 journalists who reported on the elections. We chose only 10 journalists because we wanted to extract in-depth narratives from these journalists. Moreover, this was in addition to data from a bigger study that also involved interviewing all categories of journalists who covered elections. Of the 10 journalists, five were broadcast journalists while five were print journalists. Seven of the 10 journalists were male while three were female. This is because Uganda has more male than female journalists, especially the ones covering politics. The exact number of journalists in Uganda is not known because of lack of an umbrella organisation that can register journalists across the country, but conservative estimates put the number at around 1,000. This study targeted only journalists who covered the 2016 elections on a regular basis rather than those who wrote one-off stories about elections. This was aimed at getting journalists with a wealth of experience in reporting elections. To identify these journalists, we conducted a content analysis of newspapers and reviewed radio and TV newscasts that happened during elections to ascertain who the reporters were. In cases where it was not easy to verify which reporters had reported certain stories, editors guided us to the right reporters. The selected journalists belonged to both the state-owned media and privately owned media houses.

We used a semi-structured interview guide to ask the journalists about their experiences during the coverage of elections. On the basis of responses we received from the interviewees, we often probed whenever points of interest were mentioned. All interviews were conducted at the journalists' places of work for purposes of convenience. Interviews lasted between 15 to 38 minutes depending on how much information the sources were willing to share with us. Due to the sensitivity of issues our sources discussed with us, we agreed that we shall not make specific descriptions that may lead to their identification as this could culminate into reprisals such as dismissals. Interviews were transcribed and analysed to identify the themes that emerged.

The HRNJ-U Press Index Report that was used to supplement the qualitative data was compiled basing on reports HRNJ-U received from journalists during 2016 plus cases of media freedom violations that were reported in the media. Other information of unreported cases was acquired through interviewing journalists in different newsrooms, both print and electronic across the country. It should be noted that although the election campaign period takes approximately 90 days in Uganda, the compilation of this report is based on events of a full calendar year. This is because election activities are not only restricted to the official campaign period. The extended period helped in capturing media freedom violation incidents before, during, and shortly after elections.

\section{Findings}

\subsection{Forms of Media Freedom Violations during Elections}

During the 2016 election year, HRNJ-U recorded 135 cases of infringement on the right of journalists to report. Most of these cases were assault on journalists by both state and non-state actors (HRNJ-U, 2016). Due to the severity of the nature of assaults, some victims had to stay away from work as they nursed the wounds occasioned on them. Unfortunately, many of the journalists in Uganda are freelancers and have no medical insurance. This means that in crisis situations like these, they are unable to work and sometimes they are also unable to take care of their medical bills.

It is important to note that assault of journalists is not only done by the state security agencies. In a charged election atmosphere, some ordinary citizens also assault journalists they regard as 'biased' against their candidate. For example, in the middle of the presidential and parliamentary elections campaigns on 22 December 2015, supporters of Jacob Oulanyah, the deputy speaker of parliament, beat up journalists covering opposition presidential candidate Kizza Besigye (FHRI, 2016). Other forms of violation of media freedom include malicious arrest and detention of journalists on trumped up charges. Journalists were arrested whenever the police and the army found them covering what is deemed as sensitive issues. One such arrest happened in February 2016 shortly after the winner of the 2016 elections was announced. A female TV reporter, Bahati Remmy, was arrested while reporting live on air. The arrest happened near the home of the leading opposition candidate, Kizza Besigye, who was then under house arrest, as the reporter further explains:

Journalism is not a crime. It's a public good. Our only crime is, we have the courage to tell stories the way they are...As you can see, we have been arrested by police and they are taking us away to an unknown destination. (HRNJ-U, 2016, p. 44) 
Sometimes journalists face more than one form of freedom violation. They are sometimes arrested and at the same time assaulted during and after arrest, as the same journalist further narrated.

I was covering a story at the home of Besigye, when police arrested and detained me at Kasangati police station. While in the police van, I was beaten and my hair was pulled by police officers inside the van. My cameraman Badebye Godfrey was also hit on the head and he is in severe pain. I was treated in a very inhumane way, even when I surrendered, the policemen kept pushing me around. (HRNJ-U, 2016, p. 44)

The above case is not an isolated incident because many more journalists were arrested mainly by police in other incidents. For example, NTV cameraman Abubaker Zirabamuzaale and reporter Suhail Mugabi were thrown onto a waiting police van while other remaining journalists like Eriasa Mukiibi Sserunjogi of Daily Monitor and Abubaker Lubowa were harassed by police while waiting to cover a meeting between two opposition candidates (FHRI, 2016). Other journalists who were arrested while covering elections include two $\mathrm{BBC}$ journalists who were arrested while filming Abim Hospital in North Eastern Uganda, which was then in the spotlight for its dilapidated state after a visit by an opposition candidate Kizza Besigye. The two journalists were later released without any charge (The Observer, 2016).

Another common form of media freedom violation that happens during elections is denial of access to information or news sources. During election campaigns, security officers sometimes screen journalists and deny access to those they consider to be reporting about the candidate in a critical manner as one journalist explains:

I wrote a story documenting all the times that the president [Yoweri Museveni] had campaigned past $6 \mathrm{pm}$, which was the time that the electoral commission guidelines set for all campaigns to end. When the story was published, the next day I was told to leave the president's campaign trail under the pretext that they no longer had slots in their convoy for some of us. (Personal communication, Reporter A, April 10, 2019)

Apart from this incident, NTV journalists were also denied access to incumbent Yoweri Museveni rallies for refusing to use campaign video footage produced by the candidate's media team in their news bulletins. In other cases, candidates incited the public against some media houses by alleging that they were biased against them. For example, in the middle of the 2016 campaigns, reporters who were covering opposition candidate Kizza Besigye from the government owned New Vision newspaper, told us during interviews that they were forced to remove the newspaper company name and branded materials from the vehicle they were travelling in for fear of being attacked by mobs loyal to the candidate. This fol- lowed constant claims by the candidate that this newspaper and its subsidiaries were negatively reporting about him. The candidate had also asked his supporters to boycott buying New Vision media products.

Another common form of media freedom violation during election periods, is the malicious damage, stealing and confiscation of journalists' working tools. This normally takes place during scuffles and arrests of journalists. When a journalist is found taking pictures or filming incidents, the police can break the camera using the same clubs they use to assault journalists. In some cases they can confiscate cameras as crime evidences but journalists sometimes never get back their equipment again. There are also cases when the security compels journalists to delete pictures and videos that capture security forces violating the rights of people during elections. There have also been suspicious robberies at hotels where journalists stay during election campaigns. Some leads into these robberies have indicated that they could be motivated by the desire to stop journalists from working rather than the need to take the equipment for other use.

\subsection{Perpetrators of Media Freedom Violations}

As indicated in the above section, in Uganda, the police that should be charged with protecting journalists is at the same time the leading violator of the rights of journalists. As Table 1 indicates, $61 \%$ of all incidents of media freedom violation recorded in 2016 were committed by the police. The majority of these cases were the rampant arrests and assault of journalists. The main reason why the police interfere with the work of journalists, especially during elections is because journalists expose the police's biased tendencies by protecting supporters of the incumbent presidential candidate while suppressing, assaulting, and dispersing opposition supporters.

Another major source of media freedom violation during elections are the members of the public (community) accounting for $17 \%$ of all cases reported in 2016. During an election year, attacks on journalists by ordinary people tend to escalate due to the emotions and tension that run high during election periods. Most of the assaults by the public against journalists have happened during scuffles. These assaults are normally a product of accusations of biases against a particular section of journalists. As mentioned earlier, some of these acts have taken place after candidates inciting the public against some sections of the media. A worrying trend in Uganda is that during every election, leading political parties assemble some form of militias (paramilitary groups) that sometimes descend on journalists and other people believed to be opposing their candidate to assault them (Mwanje, 2010)

\subsection{Self-Censorship during Elections}

On the basis of the above-mentioned forms and sources of media freedom violations, many journalists have re- 
Table 1. Perpetrators of media freedom violations.

\begin{tabular}{cllcr}
\hline & Perpetrator & Type of actor & No. of violations reported & Percentage \\
\hline 1. & Uganda Police Force & State & 83 & $61 \%$ \\
2. & Community members & Non state & 24 & $17 \%$ \\
3. & Employer/Radio management & Non state & 8 & $6 \%$ \\
4. & Members of parliament & Quasi state & 5 & $3.7 \%$ \\
5. & Judiciary & State & 3 & $2.2 \%$ \\
6. & Private security guards & Non state & 3 & $2.2 \%$ \\
7. & Uganda Peoples' Defense Forces & State & 2 & $1.5 \%$ \\
8. & Resident District Commissioners & State & 3 & $2.2 \%$ \\
9. & Political party (NRM) & Quasi state & 2 & $1.5 \%$ \\
10. & Local Council members & State & 1 & $0.7 \%$ \\
11. & Uganda Prison Services & State & 1 & $0.7 \%$ \\
\hline
\end{tabular}

Source: HRNJ-U (2016).

sorted to self-censorship as a strategy to stay safe while covering elections. One of the major causes of self-censorship among journalists covering elections in Uganda is the practice of embedding with candidates. The main presidential candidates normally hire press vans that carry journalists that travel alongside the candidate. Because of this proximity, the journalists' professional judgment sometimes gets corrupted as one reporter explains:

I have found that sometimes when journalists are embedded with candidates for a long time, they begin to behave as if they are an extension of the candidate's campaign machinery, which sometimes leads to selfcensorship. One person with whom I reported on the Besigye campaign in 2015-2016 eventually ended up becoming his personal assistant. Others with whom I reported on Museveni's campaign either became RDCs [Resident District Commissioners], official State House photographers, or media and communications assistants at the president's office. (Personal communication, Reporter B, April 10, 2019)

The above view was shared by another journalist who noted that when you are embedded with President Museveni's campaign team, you are given instructions on what you have to do and if you do not comply with the instructions, they drop you off the campaign trail. One of such instructions is that you must portray the president in a positive light by way of indicating in the story and the pictures that the candidate drew huge crowds wherever he went to campaign.

There are stories you come across but you cannot write them. For example, one time the President's car knocked a child dead but no journalist wrote that story because it was dangerous. In another incident, President's motorcade knocked three people dead but still no one ran that story. Even if I had written that story, it would still not come out because I work for a newspaper partly owned by the government. (Personal communication, Reporter C, April 15, 2019)

In other cases, journalists self-censor information concerning matters such as police and army brutality against civilians and bribing of voters because they are embedded with candidates. Other information that may be censored by journalists include off-the-record conversations that you are unlikely to refer to while doing your stories because the source did not authorise you to use the information. If you go ahead and use that information nevertheless, you are likely to lose access to more insider information at a later stage of the campaign process. The campaign teams also use access to their candidate as a weapon to kill certain stories. Journalists who are more objective are denied access to the candidate until they 'shape up' while those who tow the party line can interview the candidate as and when they wish.

As evident in the above analysis, both journalists working for government-owned media and those from private media face challenges when it comes to reporting the truth. Government-owned media houses are expected to write stories that glorify the incumbent president. Reporters have to relay what the president says in campaigns no matter whether it is the same promise he has made in the last three elections as another reporter explains:

The [media owner's] influence is big because you don't have free latitude to write what you may have wanted because you know that if you took a certain angle, it [the story] would not run; they would even tell you to change it. There is one time I was in Arua when Besigye said that Museveni had turned this country into a family project and I finished writing the story. When it reached New Vision newsroom, they called me and directed, "change the angle." (Personal communication, Reporter D, April 20, 2016) 
The other major cause of self-censorship relates to the economic survival of media houses. During elections, major presidential and parliamentary candidates advertise with media houses. These advertisements become an unwritten contract between the candidate and the media house against critical stories. Government bodies that are usually the biggest advertisers tend to spend a lot of money around this time especially in supplements that show what the incumbent has accomplished. This is intended to solicit favourable coverage for the incumbent:

In many cases candidates that advertise with the media are given glowing coverage and are less scrutinised. This, in my view is a form of self-censorship. Secondly institutions like Electoral Commission that manage elections also spend a lot of money on advertisement, therefore insulating themselves against critical coverage. I remember during the 2011 campaigns, the ministry of Public Service gave our newspaper a one-off advert worth about 120 million shillings $[\$ 32,000]$. They insisted that a lead story [related to the advert] be written. The newspaper management complied. (Personal communication, Reporter E, April 15, 2019).

\section{Conclusion: Implications of Self-Censorship on the Credibility of Journalism and Democracy}

The restrictive working environment for journalists in Uganda has serious consequences for the growth and relevancy of journalism to society as well as democratic rule. The profession continues to be unattractive to many journalists and aspiring journalists partly because of lack of freedom to report. As a result, more experienced journalists continue to leave the profession in search of greener pastures in NGOs and government agencies.

The continued self-censorship of election news means that citizens go to vote on the basis of biased information. In terms of democracy, this presents a worrisome situation when you have a media system that cannot hold leaders accountable. As Frere (2011, p. 246) has noted, if journalists are not free to report, neither can the electoral process be viewed as free. The infringement on the right to report remains a stumbling block in the way of citizens' right to access information and an obstacle to free and fair elections. Journalists require access to important information to adequately perform the watchdog function.

The harassment of journalists and preventing them from accessing some news sources as well as commercial considerations narrow their reporting scope, eventually leading to unbalanced information as a result of self-censorship. Due to threats and violence highlighted in this article, a sense of fear continues to engulf the media sector that causes reporters to tread with caution.

For a country to enjoy ranking among those with democratic rule, it is not enough to claim observance and respect for press freedom, but these must be seen to be actively guarded. This extends to journalists' safety, which is taken as a pre-condition for free expression and free media (Orgeret, 2016c) and "limiting the principle of free expression in all media is tantamount to undermining democracy" (Ronning, 2016, p. 43). In Uganda, there tends to be more of lip-service to this than actual visible commitment. Speaking from his experience as a former Managing Editor of Sunday Monitor, Bichachi (2013), points out that although the state in Uganda might appear ambivalent many times, ultimately it remains one of the biggest challenge to media freedom. He argues that although the National Resistance Movement government may not appear outright hostile to the media like the previous regimes, the paranoia over the media has not been any less. So as Ronning (2016) reasons, the claim that one feels offended by some media is not a reason to limit tolerance or free speech arguing that "to limit this fundamental right is to undermine the very principle of democracy" (p. 50). Thus, for countries like Uganda that do not ensure safety of journalists, one can posit that democracy is at stake.

While all citizens are entitled to enjoy their freedoms, there is particular concern for journalists because of their unique functions they perform in society. Once the freedom of journalists is violated, then freedoms of society have also been violated. If journalists' access to information is restricted, then it is all society that suffers since they are deprived of getting the information they need to make informed decisions. Although national governments are expected to ensure a conducive work environment for journalists, due to working in a globalised media environment, the international community is also expected to carry out the R2P journalists globally.

\section{Acknowledgments}

This article is based on data collected from a $\mathrm{PhD}$ research study under the Norwegian Programme for Capacity Development in Higher Education and Research for Development (NORHED) at Makerere University, Kampala (NORHED Project UGA-13/0015).

\section{Conflict of Interests}

The authors declare no conflict of interest.

\section{References}

Bellamy, A. J. (2010). The responsibility to protectFive years on. Ethics \& International Affairs, 24(2), 143-169. https://doi.org/10.1111/j.1747-7093. 2010.00254.x

Bichachi, O. (2013, June 2). The dark history of Uganda's media and past governments. Daily Monitor. Retrieved from https://www.monitor.co.ug/ Magazines/PeoplePower/The-dark-history-ofUganda-s-media-and-past-governments/6898441869456-mja5f3z/index.html 
Cottle, S. (2017). Journalist killings and the responsibility to report. In U. Carlsson \& R. Pöyhtäri (Eds.), The assault on journalism: Building knowledge to protect freedom of expression (pp. 21-33). Göteborg: Nordicom.

Foundation for Human Right Initiative. (2016). Human rights and elections in Uganda: A call for action. Kampala: Foundation for Human Right Initiative.

Frere, M. S. (2011). Elections and the media in postconflict Africa: Votes and voices for peace? London: Zed Books.

Friedrich-Ebert-Stiftung, \& fesmedia Africa. (2016). African media barometer: The first home grown analysis of the media landscape in Africa-Uganda 2016. Windhoek: Friedrich-Ebert-Stiftung and fesmedia Africa. Retrieved from http://library.fes.de/pdf-files/ bueros/africa-media/13547.pdf

Global Centre for the Responsibility to Protect. (2015). The responsibility to protect: A background briefing. New York, NY: Global Centre for the Responsibility to Protect. Retrieved from http://www.globalr2p.org/ media/files/r2p-backgrounder.pdf

Høiby, M., \& Ottosen, R. (2016). Reduced security for journalists and less reporting from the frontline. In U. Carlsson (Ed.), Freedom of expression and media in transition (pp. 183-190). Göteborg: Nordicom.

Human Rights Watch. (2016). "Keep the people uninformed": Pre-election threats to free expression and association in Uganda. Human Rights Watch. Retrieved from https://www.hrw.org/report/2016/01/ 10/keep-people-uninformed/pre-election-threatsfree-expression-and-association-uganda

Human Rights Network for Journalists-Uganda. (2016). Tough times: Political intolerance stifles media (Press freedom index report-2016). Human Rights Network for Journalists-Uganda: Kampala. Retrieved from https://hrnjuganda.org/?wpfb_dl=66

International Commission on Intervention and State Sovereignty. (2001). The responsibility to protect: Report of the international commission on intervention and state sovereignty. Ottawa: International Development Research Centre. Retrieved from https://www.idrc.ca/en/book/responsibility-protectreport-international-commission-intervention-andstate-sovereignty

Mirza, J. (2009). Globalization of media: Key issues and dimensions. European Journal of Scientific Research, 29(1), 66-75.

Mwanje, R. (2010, July 2). DP forms militia to counter Kiboko Squad. Daily Monitor. Retrieved from https://www.monitor.co.ug/News/National/ 688334-950696-bq0c6iz/index.html

Nohrstedt, S. A. (2016). 'Mediatization' of war and 'martialization' of journalism: The twins threatening democracy and human rights in the new wars. In U. Carlsson (Ed.), Freedom of expression and media in transition (pp. 155-164). Göteborg: Nordicom.

Ntulume, C. (2016). Justified mission? Press coverage of
Uganda's military intervention in the South Sudan conflict. In K. S. Orgeret \& W. Tayeebwa (Eds.), Journalism in conflict and post conflict conditions: Worldwide perspectives (pp. 39-62). Göteborg: Nordicom.

Orgeret, K. S. (2016a). Introduction: Conflict and postconflict journalism: Worldwide perspectives. In K. S. Orgeret \& W. Tayeebwa (Eds.), Journalism in conflict and post conflict conditions: Worldwide perspectives (pp. 13-22). Göteborg: Nordicom.

Orgeret, K. S. (2016b). Women making news. Conflict and post-conflict in the field. In K. S. Orgeret \& W. Tayeebwa (Eds.), Journalism in conflict and post conflict conditions: Worldwide perspectives (pp. 99-114). Göteborg: Nordicom.

Orgeret, K. S. (2016c). Women in war: Challenges and possibilities for female journalists covering wars and conflicts. In U. Carlsson (Ed.), Freedom of expression and media in transition (pp. 165-174). Göteborg: Nordicom.

Ronning, H. (2016). On media freedom and other media freedoms. In U. Carlsson (Ed.), Freedom of expression and media in transition (pp. 43-52). Göteborg: Nordicom.

Sarikakis, K. (2017). Assaults against journalists: We see the tip of the iceberg. In U. Carlsson \& R. Pöyhtäri (Eds.), The assault on journalism: Building knowledge to protect freedom of expression (pp. 119-129). Göteborg: Nordicom.

Sekeba, D. S. (2016). The media bullets in Uganda: A reference guide to history of newspapers, their role in the church and politics of Uganda. Kampala: Angel Agencies.

Skjerdal, T. S. (2013). Competing loyalties: Journalism culture in the Ethiopian media (Unpublished Doctoral dissertation). University of Oslo, Oslo, Norway.

Sparks, C. (2011). South African media in comparative perspective. African Journalism Studies, 32(2), 5-19.

Ssenoga, G. (2018, October 7). How the Ugandan media has borne the brunt of censorship for decades. The Conversation. Retrieved from https:// theconversation.com/how-the-ugandan-media-hasborne-the-brunt-of-censorship-for-decades-103108

The Observer. (2016, February 7). BBC journalists arrested for filming Abim hospital. The Observer. Retrieved from https://www.observer.ug/newsheadlines/42472-bbc-journalists-arrested-forfilming-abim-hospital

Torsner, S. (2017). Measuring journalism safety: Methodological challenges. In U. Carlsson \& R. Pöyhtäri (Eds.), The assault on journalism: Building knowledge to protect freedom of expression (pp. 129-141). Göteborg: Nordicom.

Uganda Communications Commission. (2018). Post, broadcasting and telecommunications market \& industry (Q2 Report, 2018). Kampala: Uganda Communications Commission. Retrieved from https:// www.ucc.co.ug/wp-content/uploads/2017/09/ Communication-Sector-Performance-for-the- 
Quarter-ending-June-2018.pdf

UNESCO. (2018a). World trends in freedom of expression and media development (2017/2018 Global Report). Paris: UNESCO.

UNESCO. (2018b). Assessment of media development in Uganda based on UNESCO's media development indicators. Paris: UNESCO.

Walulya, G. (2018). Hybrid journalism? An investigation into press coverage of elections in East Africa's oneparty dominant states of Tanzania and Uganda (Unpublished Doctoral dissertation). University of Oslo, Oslo, Norway.

World Association for Christian Communication, \&
Uganda Media Women's Association. (2015). Who makes the News? (Global Media Monitoring Project 2015, Uganda). Toronto and Kampala: World Association for Christian Communication and Uganda Media Women's Association. Retrieved from http://cdn.agilitycms.com/who-makes-the-news/ Imported/reports_2015/national/Uganda.pdf

Yiga, S. (2019, February 7). Arrested journalists were doing their work-Colleagues. New Vision. Retrieved from https://www.newvision.co.ug/new_ vision/news/1493830/arrested-journalists-doingcolleagues

\section{About the Authors}

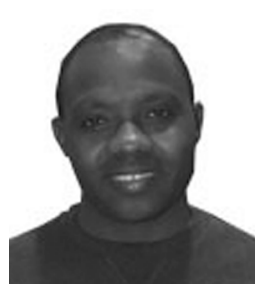

Gerald Walulya is a Lecturer and Projects Coordinator at the Department of Journalism and Communication, Makerere University, Uganda. He holds a PhD in Media and Communication from the University of Oslo, Norway. Before joining academia, he worked as a political reporter at a privately owned Daily Monitor newspaper in Uganda. His research interests are political communication, journalism, and freedom of expression.

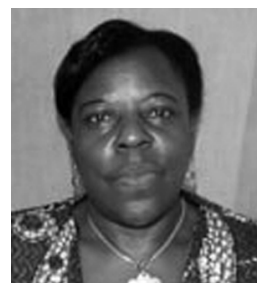

Goretti L. Nassanga is Founder Head of the Department of Journalism and Communication, Makerere University Kampala, where she continues to work. She has had a long and rich media experience, starting off as a journalist in 1979 and moving into training, consultancy, and research in 1990. She has published widely in international peer-reviewed journals and books. In 2017, she received the highly prestigious Media Life Time Achievement Award in recognition of her outstanding contribution to Uganda's media. 